\title{
An ABET Preparation Perspective Under the New Proposed Criteria 3 and 5
}

\author{
Ronald E. Barr \\ University of Texas at Austin
}

\begin{abstract}
This paper presents the author's perspective on how to prepare for an ABET accreditation visit under the new proposed criteria 3 and 5. The author's perspective is based on experience from navigating three ABET visits under the old EC2000 criteria and participating in the recent 2016 ASEE town hall meeting in New Orleans where these new criteria were broadly discussed. The focus of the paper will be on the proposed changes to criteria 3 and 5, and the current process that will eventually lead to their likely adoption. Because of the success ABET has experienced with its outcomes-based assessment process, the future focus for ABET evaluators will continue to be on attainment of the Student Outcomes (SO's) enumerated in the new proposed criterion 3. The paper suggests ways to measure and evaluate attainment of SO's using both direct and indirect measures. The final part of the paper will focus on the Program Educational Objectives (PEO's) of criterion 2, and their relationship to both the SO's and the institutional goals.
\end{abstract}

\section{Keywords}

Accreditation, ABET Criteria.

\section{Introduction}

In the mid-1990's, ABET developed a new set of criteria (called EC2000) for accrediting engineering degree programs. The new criteria changed the focus of accreditation from a review of curriculum and courses, to an assessment of student attainment of program outcomes. The initial set of eleven outcomes (a) through( k) spanned knowledge and skills across a spectrum of technical, professional, and societal needs. Unfortunately, the original listing of (a) through (k) was never vetted or properly organized by ABET, and caused confusion amongst engineering educators involved in preparing for an accreditation visit. Nonetheless, 20 years later, it has generally been accepted that student outcomes-based assessment was a good thing for engineering education, and ABET has become a global "gold-standard" for accreditation practices because of it.

The main problems with the original outcomes in Criteria 3 are the wordings of the statements. Each word in itself becomes critical, and different engineering constituents want different words in the outcome statements. Our Mechanical Engineering (ME) group took a different approach. Instead of starting with long statements for outcomes, our group started with one- or two-word "desirable traits" that engineers should possess, and then mapped the published ABET (a) through $(\mathrm{k})$ outcomes into those desirable traits. This resulted in Table 1. In some ways, the original (a) through $(\mathrm{k})$ outcomes are a remarkable compilation in that they captured all the desired traits sought by our group, but just in a mixed-up fashion. 
Table 1: Mapping of Student Traits, ABET (a) through (k), and ME Student Outcomes (circa 2004).

\begin{tabular}{|l|l|l|}
\hline \multicolumn{1}{|c|}{ Desired Traits } & \multicolumn{1}{|c|}{ ABET Student Outcomes } & \multicolumn{1}{c|}{ ME Student Outcomes } \\
\hline Fundamentals & $\begin{array}{l}\text { (a) an ability to apply knowledge of } \\
\text { mathematics, science, and engineering }\end{array}$ & $\begin{array}{l}\text { 1. Knowledge of and ability to apply } \\
\text { engineering and science fundamentals to } \\
\text { real problems. }\end{array}$ \\
\hline Problem Solving & $\begin{array}{l}\text { (e) an ability to identify, formulate, and } \\
\text { solve engineering problems }\end{array}$ & $\begin{array}{l}\text { 2. Ability to formulate and solve open- } \\
\text { ended problems. }\end{array}$ \\
\hline Design & $\begin{array}{l}\text { (c) an ability to design a system, } \\
\text { component, or process to meet desired } \\
\text { needs }\end{array}$ & $\begin{array}{l}\text { 3. Ability to design mechanical } \\
\text { components, systems and processes. }\end{array}$ \\
\hline Experimentation & $\begin{array}{l}\text { (b) an ability to design and conduct } \\
\text { experiments, as well as to analyze and } \\
\text { interpret data }\end{array}$ & $\begin{array}{l}\text { 4. Ability to set up and conduct } \\
\text { experiments, and to present the results in } \\
\text { a professional manner. }\end{array}$ \\
\hline Communication & $\begin{array}{l}\text { (k) an ability to use the techniques, skills, } \\
\text { and modern engineering tools }\end{array}$ & $\begin{array}{l}\text { 5. Ability to use modern computer tools } \\
\text { in mechanical engineering. }\end{array}$ \\
\hline Teamwork & (g) an ability to communicate effectively & $\begin{array}{l}\text { 6. Ability to communicate in written, oral } \\
\text { and graphical forms. }\end{array}$ \\
\hline Independent Study & $\begin{array}{l}\text { (d) an ability to function on multi- } \\
\text { disciplinary teams }\end{array}$ & $\begin{array}{l}\text { 7. Ability to work in teams and apply } \\
\text { interpersonal skills in engineering } \\
\text { contexts. }\end{array}$ \\
\hline Professionalism & ability to engage in life-long learning & $\begin{array}{l}\text { (f) Ability and desire to lay a foundation } \\
\text { for continued learning beyond the } \\
\text { baccalaureate degree. }\end{array}$ \\
\hline ethical responsibility & $\begin{array}{l}\text { 9. Awareness of professional issues in } \\
\text { engineering practice, including ethical } \\
\text { responsibility, safety, the creative } \\
\text { enterprise, and loyalty and commitment } \\
\text { to the profession. }\end{array}$ \\
\hline Pocietal Issues & $\begin{array}{l}\text { (h) the broad education necessary to } \\
\text { understand the impact of engineering } \\
\text { solutions in a global and societal context } \\
\text { j) a knowledge of contemporary issues }\end{array}$ & $\begin{array}{l}\text { engineering practice, including economic, } \\
\text { social, political and environmental issues, } \\
\text { and global impact. }\end{array}$ \\
\hline
\end{tabular}

\section{ASEE Town Hall Meeting}

A town hall meeting was held at the 2016 ASEE Annual Conference in New Orleans to discuss the proposed changes to ABET criteria 3 and 5. An ASEE feedback committee had earlier accepted and compiled member input before the live meeting and had posted those comments on the ASEE website. This was presented at the town hall meeting as a set of preliminary statements for the audience to consider. After a brief panel presentation in front of a packed room, breakout sessions were formed to discuss the specific areas of interest related to the proposed changes to ABET criteria 3 and 5. The feedback committee took the new comments and then went back and revised the preliminary statements to a final PDF document called "Summary of ASEE Member Views on Proposed Changes to ABET Engineering Accreditation Standards." This PDF document was then submitted to ABET and its Engineering Accreditation Commission (EAC) Criteria Committee, and also distributed to the ASEE membership via Division, Council, and Section chairs. The PDF document may be found at the following link: https://aseetownhall.wordpress.com/2016-town-hall/. 


\section{Current Status of Proposed Changes to ABET Criteria 3 and 5}

In late October of 2016, the ABET Engineering Area Delegation released the most current proposed changes to Criteria 3 and 5 for one final public review and comment. This gives the EAC Criteria Committee another opportunity to get constituent feedback that can be used to ensure the proposed changes are as clear, effective, and inclusive as possible. A preliminary inspection of the proposed changes by this author shows that the ASEE town hall comments did have a significant effect on their current status. ABET released these proposed changes in sideby-side tables comparing the 2015 proposed changes versus the 2016 proposed changes. The proposed changes can be discussed in four parts: preamble, definitions, criteria 3 , and criteria 5 .

Table 2 shows the side-by-side comparison of the preamble. It is heartening to see that all the outcome-sounding terms, such as diversity, manufacturability, sustainability, and global dimensions, were removed. This was a major concern at the ASEE town hall meeting, that these terms sounded like criteria, but were unenforceable when placed in the preamble. So this is a positive result that was influenced by our input.

Table 2: Side-by-Side Comparison of Proposed Changes to the Preamble (source: $\mathrm{ABET}^{1}$ ).

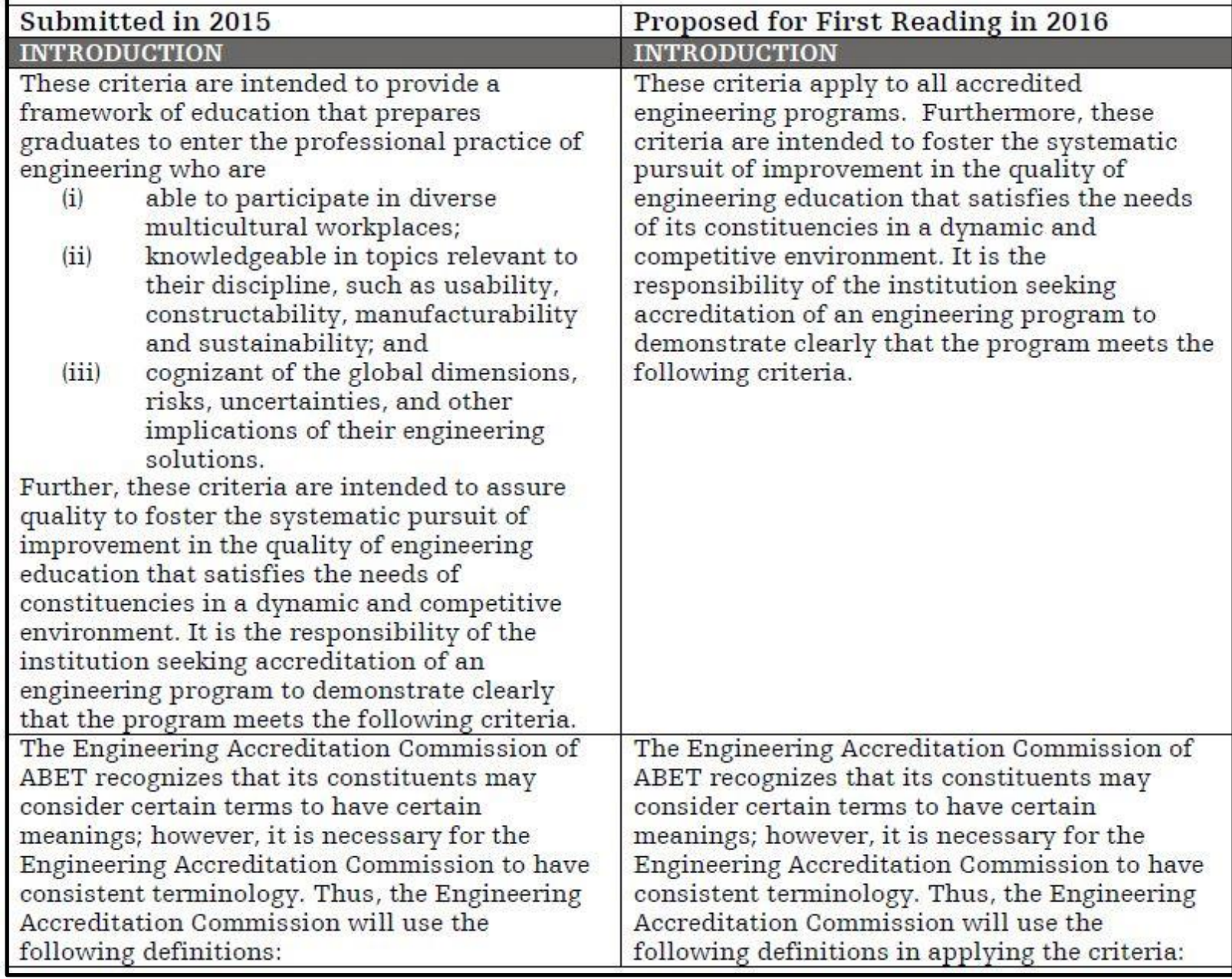

Proceedings of the 2017 ASEE Gulf-Southwest Section Annual Conference Organized by The University of Texas at Dallas Copyright $@$ 2017, American Society for Engineering Education 
Table 3 shows the side-by-side comparison of the proposed ABET definition of terms. Several changes proposed in the 2016 column stand out. Overall, most definitions are now longer, which underscores the many inputs from broad and diverse constituents. The definition of "Basic Science" is clarified to include chemistry, physics, and nature sciences (life, earth, space). The definition of "Mathematics" now lists specific courses such as calculus, differential equations, probability, statistics, linear algebra, and discrete mathematics. The definition of "Engineering Design" has been almost doubled in wording. It broadens the definition of the design process to include synthesis and analysis under a broad set of illustrative constraints such as aesthetics, constructability, manufacturability, and sustainability. The definition of "Team: has strengthened the desirability of diversity and inclusion on engineering teams. The definition of "Academic Year" has been deleted and is no longer used in criteria 5 as a benchmark for minimum credit hours needed in the various categories. The expansion (or elimination) of these definitions helps to make the proposed 2016 changes as clear, effective, and inclusive as possible. However, it is not clear how much these definitional terms will be used by PEV's in their assessment of whether a program meets ABET criteria during their review of the program.

Table 4 shows the side-by-side comparison of the proposed ABET criterion 3, and a specific listing of the seven student outcomes that are the core of criterion 3. One can first note that several of the student outcomes $(1,3,4,5)$ show very little change between the 2015 and 2016 versions. The three remaining outcomes show some changes worth mentioning. Student outcome 2, pertaining to design, has expanded the need to consider "public health and safety, and global, cultural, social, environmental, economic, and other factors as appropriate to the discipline." This will require the need for more granularity in the assessment of student design work when evaluating attainment of student outcome 2. Student outcome 6, which pertains to independent learning, includes the phrase "choose appropriate learning strategies" and will be difficult to demonstrate. Finally, new student outcome 7, pertaining to teamwork, includes the need to "create a collaborative and inclusive environment." This outcome 7 continues to underscore ABET's desire to promote diversity and inclusion in engineering education.

Table 5 shows the side-by-side comparison of the proposed ABET criterion 5, pertaining to the curriculum. In the introductory part of proposed new criterion 5, the curriculum must be both "consistent with the student outcomes and program educational objectives (PEO's) to ensure that students are prepared to enter the practice of engineering." Thus the program will need to demonstrate how the curriculum will now map both to the student outcomes as well as the PEO's. Since the definition of one academic year has been deleted, the new requirement in criterion 5 (a) is that the curriculum must have a minimum of 30 credit hours of mathematics and science. For some programs, this new minimum of 30 credit hours is a relief from previous values of 32 or higher credit hours. So new criterion 5 (a) will be greeted favorably. Likewise, due to the elimination of the term academic year, new criterion 5 (b) requires that the curriculum must have a minimum of 45 credit hours of engineering topics. This also will be a relief for many programs that previously needed 48 or more credit hours of engineering courses to meet the ABET standards. Also, an old term in previous ABET outcomes, "utilizing modern engineering tools," has been added to curriculum criterion 5 (b). One may recall that modern engineering tools was part of the original ABET outcome (k) in the (a) through (k) listings (see Table 1). This placement in criterion 5 (c) now seems to be appropriate.

\section{Proceedings of the 2017 ASEE Gulf-Southwest Section Annual Conference Organized by The University of Texas at Dallas Copyright $@$ 2017, American Society for Engineering Education}


Table 3: Side-by-Side Comparison of Proposed Changes to Definitions (source: $\mathrm{ABET}^{1}$ ).

\begin{tabular}{|l|l|}
\hline Submitted in $\mathbf{2 0 1 5}$ & Proposed for First Reading in 2016 \\
\hline $\begin{array}{l}\text { Basic Science - Basic sciences consist of } \\
\text { chemistry and physics, and other biological, } \\
\text { chemical, and physical sciences, including } \\
\begin{array}{l}\text { astronomy, biology, climatology, ecology, } \\
\text { geology, meteorology, and oceanography. }\end{array}\end{array}$ & $\begin{array}{l}\text { Basic Science - Basic sciences are disciplines } \\
\text { focused on knowledge or understanding of the } \\
\text { fundamental aspects of natural phenomena. } \\
\text { Basic sciences consist of chemistry and physics } \\
\text { and other natural sciences including life, earth, } \\
\text { and space sciences. }\end{array}$ \\
\hline $\begin{array}{l}\text { College-level Mathematics - College-level } \\
\text { mathematics consists of mathematics above } \\
\text { pre-calculus level. }\end{array}$ & $\begin{array}{l}\text { College-Level Mathematics - College-level } \\
\text { mathematics consists of mathematics that } \\
\text { requires a degree of mathematical } \\
\text { sophistication at least equivalent to that of } \\
\text { introductory calculus. For illustrative } \\
\text { purposes, some examples of college-level } \\
\text { mathematics include calculus, differential } \\
\text { equations, probability, statistics, linear } \\
\text { algebra, and discrete mathematics. }\end{array}$ \\
\hline
\end{tabular}

Engineering Science - Engineering sciences are based on mathematics and basic sciences but carry knowledge further toward creative application needed to solve engineering problems.

Engineering Design - Engineering design is the process of devising a system, component, or process to meet desired needs, specifications, codes, and standards within constraints such as health and safety, cost, ethics, policy, sustainability, constructability, and manufacturability. It is an iterative, creative, decision-making process in which the basic sciences, mathematics, and the engineering sciences are applied to convert resources optimally into solutions.

Engineering Science - Engineering sciences are based on mathematics and basic sciences but carry knowledge further toward creative application needed to solve engineering problems. These studies provide a bridge between mathematics and basic sciences on the one hand and engineering practice on the other.

Engineering Design - Engineering design is the process of devising a system, component, or process to meet desired needs and specifications within constraints. It is an iterative, creative, decision-making process in which the basic sciences, mathematics, and engineering sciences are applied to convert resources into solutions. The process involves identifying opportunities, performing analysis and synthesis, generating multiple solutions, evaluating those solutions against requirements, considering risks, and making trade-offs to identify a high quality solution under the given circumstances. For illustrative purposes only, examples of possible constraints include accessibility, aesthetics, constructability, cost, ergonomics, functionality, interoperability, legal considerations, maintainability, manufacturability, policy, regulations, schedule, sustainability, or usability.

Teams - A team consists of more than one Team - A team consists of more than one person working toward a common goal and may include individuals of diverse backgrounds, skills, and perspectives. person working toward a common goal and should include individuals of diverse backorounds, skills, or perspectives consistent with ABET's policies and positions on diversity and inclusion.

One Academic Year - One academic year is the lesser of 32 semester credits (or equivalent) or one-fourth of the total credits required for graduation with a baccalaureate degree. 
Table 4: Side-by-Side Comparison of Proposed Changes to Criteria 3 (source: $\mathrm{ABET}^{1}$ ).

\begin{tabular}{|c|c|}
\hline Submitted in 2015 & Proposed for First Reading in 2016 \\
\hline GRITERION 3. STUDENT OUTCOMES & $\begin{array}{l}\text { GENERAL CRTTERION 3: STUDENT } \\
\text { OUTCOMES }\end{array}$ \\
\hline $\begin{array}{l}\text { The program must have documented student } \\
\text { outcomes. Attainment of these outcomes } \\
\text { prepares graduates to enter the professional } \\
\text { practice of engineering. } \\
\text { Student outcomes are outcomes (1) through (7) } \\
\text { plus any additional outcomes that may be } \\
\text { articulated by the program. }\end{array}$ & $\begin{array}{l}\text { The program must have documented student } \\
\text { outcomes that support the program educationa } \\
\text { objectives. Attainment of these outcomes } \\
\text { prepares graduates to enter the professional } \\
\text { practice of engineering. Student outcomes are } \\
\text { outcomes (1) through (7), plus any additional } \\
\text { outcomes that may be articulated by the } \\
\text { program. }\end{array}$ \\
\hline $\begin{array}{l}\text { 1. An ability to identify, formulate, and solve } \\
\text { engineering problems by applying principles } \\
\text { of engineering, science, and mathematics. }\end{array}$ & $\begin{array}{l}\text { (1) An ability to identify, formulate, and solve } \\
\text { complex engineering problems by applying } \\
\text { principles of engineering, science, and } \\
\text { mathematics. }\end{array}$ \\
\hline $\begin{array}{l}\text { 2. An ability to apply both analysis and } \\
\text { synthesis in the engineering design process, } \\
\text { resulting in designs that meet desired needs. }\end{array}$ & $\begin{array}{l}\text { (2) An ability to apply the engineering design } \\
\text { process to produce solutions that meet } \\
\text { specified needs with consideration for } \\
\text { public health and safety, and global, } \\
\text { cultural, social, environmental, economic, } \\
\text { and other factors as appropriate to the } \\
\text { discipline. }\end{array}$ \\
\hline $\begin{array}{l}\text { 3. An ability to develop and conduct } \\
\text { appropriate experimentation, analyze and } \\
\text { interpret data, and use engineering judgment } \\
\text { to draw conclusions. }\end{array}$ & $\begin{array}{l}\text { (3) An ability to develop and conduct } \\
\text { appropriate experimentation, analyze and } \\
\text { interpret data, and use engineering } \\
\text { judgment to draw conclusions. }\end{array}$ \\
\hline $\begin{array}{l}\text { 4. An ability to communicate effectively with a } \\
\text { range of audiences. }\end{array}$ & $\begin{array}{l}\text { (4) An ability to communicate effectively with } \\
\text { range of audiences. }\end{array}$ \\
\hline $\begin{array}{l}\text { 5. An ability to recognize ethical and } \\
\text { professional responsibilities in engineering } \\
\text { situations and make informed judgments, } \\
\text { which must consider the impact of } \\
\text { engineering solutions in global, economic, } \\
\text { environmental, and societal contexts. }\end{array}$ & $\begin{array}{l}\text { (5) An ability to recognize ethical and } \\
\text { professional responsibilities in engineering } \\
\text { situations and make informed judgments, } \\
\text { which must consider the impact of } \\
\text { engineering solutions in global, economic, } \\
\text { environmental, and societal contexts. }\end{array}$ \\
\hline $\begin{array}{l}\text { 6. An ability to recognize the ongoing need for } \\
\text { additional knowledge and locate, evaluate, } \\
\text { integrate, and apply this knowledge } \\
\text { appropriately. }\end{array}$ & $\begin{array}{l}\text { (6) An ability to recognize the ongoing need to } \\
\text { acquire new knowledge, to choose } \\
\text { appropriate learning strategies, and to app } \\
\text { this knowledge. }\end{array}$ \\
\hline $\begin{array}{l}\text { 7. An ability to function effectively on teams } \\
\text { that establish goals, plan tasks, meet } \\
\text { deadlines, and analyze risk and uncertainty. }\end{array}$ & $\begin{array}{l}\text { (7) An ability to function effectively as a } \\
\text { member or leader of a team that establishe: } \\
\text { goals, plans tasks, meets deadlines, and } \\
\text { creates a collaborative and inclusive } \\
\text { environment. }\end{array}$ \\
\hline
\end{tabular}

In criterion 5 (c), the terms humanities and social sciences has been dropped, and the criterion now simply calls it the "broad education component that complements the technical content." Finally, a fourth criterion 5 (d) has been re-worded from a previous statement, and simplified the concept of a capstone design experience. 
Table 5: Side-by-Side Comparison of Proposed Changes to Criteria 5 (source: $\mathrm{ABET}^{1}$ ).

\begin{tabular}{|c|c|}
\hline Submitted in 2015 & Proposed for First Reading in 2016 \\
\hline CRITERION 5. CURRICULUM & GENERAL CRITERION 5: CURRICULUM \\
\hline $\begin{array}{l}\text { The curriculum requirements specify subject } \\
\text { areas appropriate to engineering but do not } \\
\text { prescribe specific courses. The curriculum must } \\
\text { support attainment of the student outcomes } \\
\text { and must include: }\end{array}$ & $\begin{array}{l}\text { The curriculum requirements specify subject } \\
\text { areas appropriate to engineering but do not } \\
\text { prescribe specific courses. The program } \\
\text { curriculum must provide adequate content for } \\
\text { each area, consistent with the student outcomes } \\
\text { and program educational objectives, to ensure } \\
\text { that students are prepared to enter the practice } \\
\text { of engineering. The curriculum must include: }\end{array}$ \\
\hline $\begin{array}{l}\text { (a) one academic year of a combination of } \\
\text { college-level mathematics and basic sciences } \\
\text { (some with experimental experience) } \\
\text { appropriate to the program. }\end{array}$ & $\begin{array}{l}\text { (a) a minimum of } 30 \text { semester credit hours (or } \\
\text { equivalent) of a combination of college-level } \\
\text { mathematics and basic sciences with } \\
\text { experimental experience appropriate to the } \\
\text { program. }\end{array}$ \\
\hline $\begin{array}{l}\text { (b) one and one-half academic years of } \\
\text { engineering topics, consisting of engineering } \\
\text { sciences and engineering design appropriate to } \\
\text { the program and utilizing modern engineering } \\
\text { tools. }\end{array}$ & $\begin{array}{l}\text { (b) a minimum of } 45 \text { semester credit hours (or } \\
\text { equivalent) of engineering topics } \\
\text { appropriate to the program, consisting of } \\
\text { engineering sciences and engineering design, } \\
\text { and utilizing modern engineering tools. }\end{array}$ \\
\hline $\begin{array}{l}\text { (c) a broad education component that includes } \\
\text { humanities and social sciences, complements } \\
\text { the technical content of the curriculum, and is } \\
\text { consistent with the program educational } \\
\text { objectives. }\end{array}$ & $\begin{array}{l}\text { (c) a broad education component that } \\
\text { complements the technical content of the } \\
\text { curriculum and is consistent with the } \\
\text { program educational objectives. }\end{array}$ \\
\hline $\begin{array}{l}\text { Students must be prepared to enter the } \\
\text { professional practice of engineering through a } \\
\text { curriculum culminating in a major design } \\
\text { experience based on the knowledge and skills } \\
\text { acquired in earlier course work and } \\
\text { incorporating appropriate engineering } \\
\text { standards and multiple constraints. }\end{array}$ & $\begin{array}{l}\text { (d) a culminating major engineering design } \\
\text { experience based on the knowledge and } \\
\text { skills acquired in earlier course work that } \\
\text { incorporates appropriate engineering } \\
\text { standards and multiple constraints. }\end{array}$ \\
\hline
\end{tabular}

\section{ABET Process to Review and Approve the Proposed Changes to Criteria 3 and 5.}

ABET is very responsive to all constituents, and as such has developed a large playing field for all interested parties to comment on any proposed changes to their accreditation standards. For example, this has already happened when the ASEE town hall was convened. There is no doubt that the significant comments they received in in the summer of 2016 put the brakes on any fasttrack approval of the 2015 proposed changes. Figure 1 shows the process to continue reviewing and eventually approve the changes to the criteria. Currently, public comments of the current 2016 proposal are being solicited ("you are here" box in the bottom left corner in Figure 1). These new comments will go back to the EAC criteria committee. This committee will then submit a proposal to the full ABET commission, which meets in the summer of 2017 . The commission then forwards the proposal to the area delegation group, who has the authority to adopt, reject, or rework the proposal. If all goes well, the new criteria would be adopted and published sometime in 2018. When the new criteria would be required is not clear, and no doubt there will be some grandfather condition for programs to use the old criteria for some years to come, perhaps until 2020. 


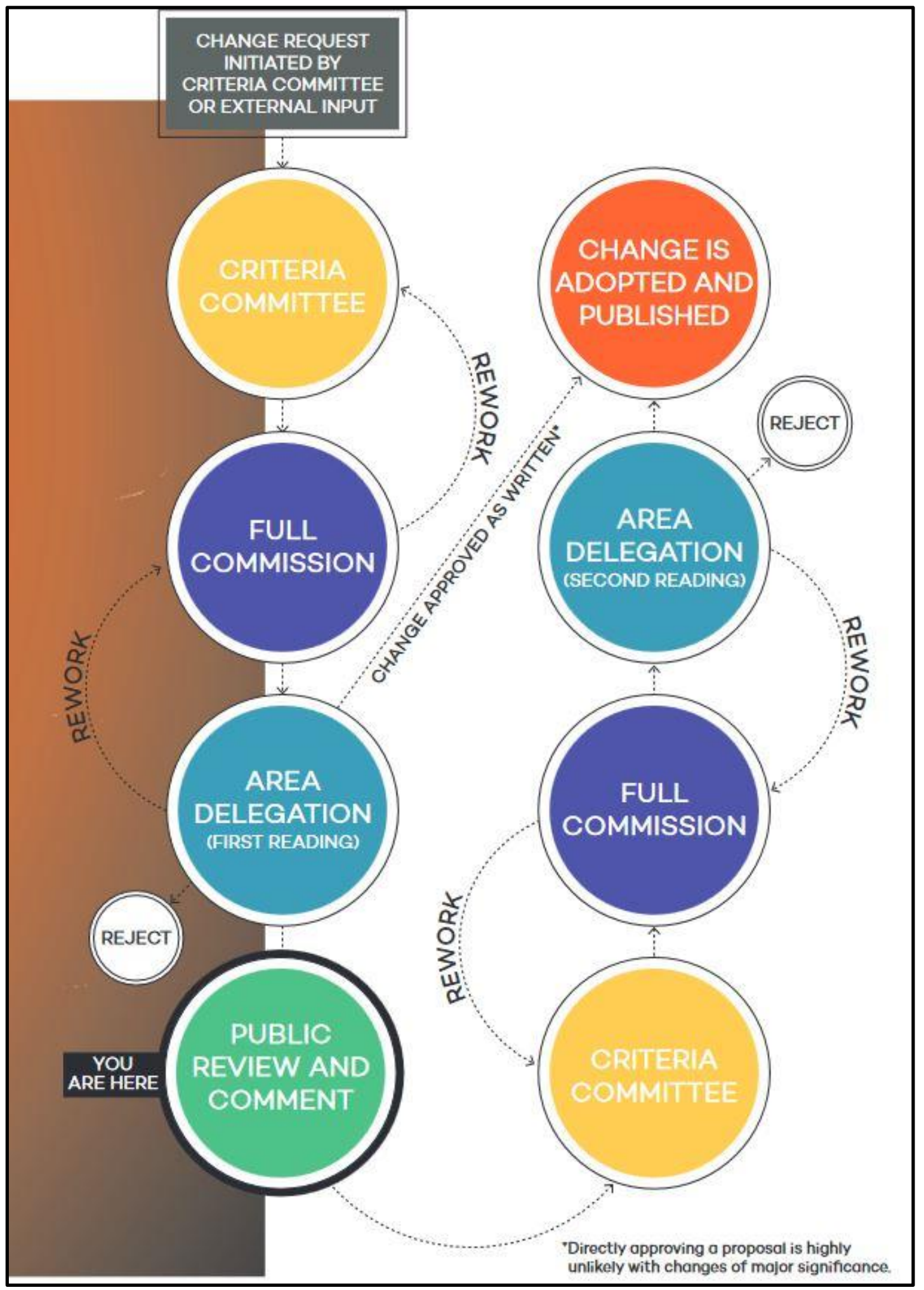

Figure 1: Flowchart of the ABET Process to Review and Approve the Proposed Changes to Criteria 3 and 5 (source $\mathrm{ABET}^{1}$ ). 


\section{Assessment of Proposed New Student Outcomes in ABET Criterion 3}

Preparing for an ABET visit is a major challenge that usually requires a departmental committee, with a dedicated chair, working over several years. There are many aspects to the accreditation process that this committee must understand and pursue. However, because of the success ABET has experienced with its outcomes-based assessment process, the future focus for ABET evaluators under the new criteria will probably continue to be on attainment of the student outcomes (SO's) enumerated in criterion 3. Thus, it is imperative that the program has a good process for assessing and evaluated student outcomes. The author's experiences from three previous ABET visits suggests two things: there should be at least two methods to assess student outcomes and there should in at least one direct method. After trying and reviewing many different methods to assess student outcomes (e.g. results of FE exam, student portfolios, etc.) the author believes the two best approaches are senior exit surveys (indirect measure) and faculty course assessment reports (direct measure).

\section{Senior Exit Surveys}

Senior exit surveys asks graduating seniors to complete a form in which they rate their attainment of each outcome using a suitable Lickert scale. This could be done in the senior capstone design course, or through exit interviews with the department chair. The survey could be given to individuals, or could be a team-based rating form, where the team members discuss the ratings amongst themselves before completing the form. Because of the complex wording structure of the proposed seven ABET student outcomes, the survey form may need two levels: one for overall outcome (global level) and one for individual wordings (granular level). For example, an evaluation form for proposed student outcome (1) may look like Figure 2.

Please rate your knowledge, skill, abilities and level of attainment for the following stated student outcomes using the following 1 to 7 numerical scale (circle best response):

$\begin{array}{ccccccc}1 & 2 & 3 & 5 & 6 & 7 \\ \text { Poor } & & \text { Average } & 4 & \text { Good } & \text { Excellent }\end{array}$

\begin{tabular}{|c|c|c|c|c|c|c|c|c|c|}
\hline $\begin{array}{l}\text { G } \\
\text { L } \\
\text { O } \\
\text { B } \\
\text { A } \\
\text { L }\end{array}$ & $\begin{array}{l}\text { (1) an ability to identify, formulate, } \\
\text { and solve complex engineering } \\
\text { problems by applying principles of } \\
\text { engineering, science, and } \\
\text { mathematics. }\end{array}$ & 1 & 2 & 3 & 4 & 5 & 6 & 7 & NA \\
\hline \multirow{6}{*}{$\begin{array}{l}\text { G } \\
R \\
\text { A } \\
\text { N } \\
\text { U } \\
\text { L } \\
\text { A } \\
\text { R }\end{array}$} & Identify Problems & 1 & 2 & 3 & 4 & 5 & 6 & 7 & NA \\
\hline & Formulate Problems & 1 & 2 & 3 & 4 & 5 & 6 & 7 & NA \\
\hline & Solve Problems & 1 & 2 & 3 & 4 & 5 & 6 & 7 & NA \\
\hline & Apply Engineering Principles & 1 & 2 & 3 & 4 & 5 & 6 & 7 & NA \\
\hline & Apply Science Principles & 1 & 2 & 3 & 4 & 5 & 6 & 7 & NA \\
\hline & Apply Mathematics & 1 & 2 & 3 & 4 & 5 & 6 & 7 & NA \\
\hline
\end{tabular}

Figure 2: Example of Senior Exit Survey Rating Form for Proposed Student Outcome (1). 


\section{Faculty Course Assessment Reports}

Faculty Course Assessment Reports (FCAR) are direct measures of student work in their engineering courses. Each semester, over a span of several years, certain required engineering courses in the program curriculum are identified for assessment. The faculty member teaching the course is asked to select samples of student work for the assessment. The student work could be samples of homework, tests, lab reports, project reports, and so forth. The sample size does not have to be large, perhaps 20 to 25 individual items that are representative of the various course activities. The student samples are then gathered and systematically rated using a student outcome rating form similar to Figure 2. The rating can be done by the course instructor, or submitted to a departmental committee in charge of the ABET process to rate the student work. Either way, the completed rating form is attached to each student sample, and then the entire collection can be placed in a student outcomes notebook, which would be available for the ABET site visit. If preferred, the FCAR process could be organized in a paperless fashion, creating and organizing the material into PDF documents. If there are 18 required engineering courses in the curriculum, and if 3 courses are selected each long semester, then the entire engineering part of the curriculum could be covered in 6 long semesters.

\section{Program Educational Objectives}

ABET is currently not proposing any changes to criterion 2, program educational objectives (PEO's). Nonetheless, since they are mentioned in the proposed changes discussed earlier, it is helpful to include some of the author's perspective on this topic. Program educational objectives are statements that describe the expected accomplishments and professional status of engineering graduates in 3-5 years after graduation. Recent and past experiences with PEO's has shown that this criterion, while seemingly a simple concept, consistently is being cited by ABET program evaluators (PEV's) with shortcomings. Most often they will challenge the PEO wording, its appropriateness as a PEO, and/or how it relates or maps to the student outcomes as well as institutional objectives.

An example of PEO's for mechanical engineering that were used in an ABET site visit in Fall 2016 are shown in Figure 3. First it is noted that these are activities and accomplishments by graduates 3-5 years after graduation. There are four PEO's articulated. The first PEO 1 is to practice engineering, since that is the direct goal of an engineering education. The second PEO 2 is to pursue advanced education and other forms of learning activities. The third PEO 3 is to become leaders that help shape economic development in their sphere of influence. The final PEO 4 is to conduct themselves in a professional and ethical manner.

Finally, in an effort to generalize these PEO's, Table 6 maps these PEO's to both desired traits of engineering graduates as well as the institutional core values. It can be seen that PEO statements should cover four core traits that we would expect for our graduates:

1 Practice Engineering

2. Advanced Learning

3. Leadership

4. Professional Responsibility.

Proceedings of the 2017 ASEE Gulf-Southwest Section Annual Conference

Organized by The University of Texas at Dallas

Copyright $₫$ 2017, American Society for Engineering Education 


\section{ME Program Educational Objectives}

These educational objectives are statements that describe the expected accomplishments and professional status of mechanical engineering graduates beyond the baccalaureate degree. The Mechanical Engineering program at The University of Texas at Austin is dedicated to graduating mechanical engineers who in 3-5 years after graduation can:

1. Practice mechanical engineering in the general stems of thermal/fluid systems, mechanical systems and design, materials, manufacturing and other emerging areas, in industry and government settings.

2. Pursue advanced education, research and development, and other creative efforts in science and technology.

3. Participate as leaders in activities that support service to and economic development of the region, state, nation, and world.

4. Conduct themselves in a responsible, professional, and ethical manner.

Figure 3: Example of Program Educational Objectives.

Table 6: Mapping of Desired Traits and Institutional Core Values with ABET Program Educational Objectives.

\begin{tabular}{|c|c|c|c|c|c|}
\hline $\begin{array}{c}\text { Desired Trait } \\
\text { of Graduate }\end{array}$ & $\begin{array}{c}\text { Institutional } \\
\text { Core Values }\end{array}$ & PEO 1 & PEO 2 & PEO 3 & PEO 4 \\
\hline $\begin{array}{c}\text { Practice } \\
\text { Engineering }\end{array}$ & $\begin{array}{c}\text { Opportunity and } \\
\text { Discovery }\end{array}$ & $\sqrt{ }$ & & & \\
\hline $\begin{array}{c}\text { Advanced } \\
\text { Learning }\end{array}$ & Learning & & $\sqrt{ }$ & & \\
\hline Leadership & $\begin{array}{c}\text { Freedom and } \\
\text { Leadership }\end{array}$ & & & $\sqrt{ }$ & \\
\hline $\begin{array}{c}\text { Professional } \\
\text { Responsibility }\end{array}$ & Responsibility & & & & $\sqrt{ }$ \\
\hline
\end{tabular}

\section{References}

1. ABET, http://www.abet.org/blog/news/proposed-eac-criteria-changes-released-for-publicreview-and-comment/

\section{Ronald E. Barr}

Ronald Barr is Professor of Mechanical Engineering at the University of Texas at Austin, where he has taught since 1978. He received both his B.S. and Ph.D. degrees from Marquette University in 1969 and 1975, respectively. His research interests are in Bio-Signal Analysis, Biomechanics of Human Movement, and Engineering Design Graphics. Barr is a recipient of the ASEE Chester F. Carlson Award, the Orthogonal Medal, and the EDGD Distinguished Service Award. Barr is a Fellow of ASEE and ASME, and served as ASEE President from 2005-2006. $\mathrm{He}$ is an ABET PEV and a registered Professional Engineer (PE) in the state of Texas. 